\title{
Long-term Trends in Fertility of Soils under Continuous Cultivation and Cereal Cropping in Southern Queensland. VII* Dynamics of Nitrogen Mineralization Potentials and Microbial Biomass
}

\author{
R. C. Dalal and R. J. Mayer \\ Queensland Wheat Research Institute, \\ Department of Primary Industries, Toowoomba, Q1d 4350.
}

\section{Abstract}

The dynamics of nitrogen mineralization potential $\left(N_{0}\right)$ and mineralization rate constant $(k)$ were studied in six major soils which had been used for cereal cropping for up to 20-70 years. In the top $0.1 \mathrm{~m}$ layer of virgin soils, $N_{0}$ varied from $110 \pm 22 \mathrm{mg} \mathrm{kg}^{-1}$ soil (Riverview) to $217 \pm 55 \mathrm{mg} \mathrm{kg}^{-1}$ soil (Langlands-Logie), representing about $13 \%$ and $11 \%$, respectively, of total $\mathrm{N}$ in these soils. Upon cultivation and cropping, $N_{0}$ declined by $1.7 \pm 0.5 \mathrm{mg} \mathrm{kg}^{-1} \mathrm{yr}^{-1}$ (Riverview) to $4.8 \pm 2.0 \mathrm{mg} \mathrm{kg}^{-1} \mathrm{yr}^{-1}$ (Billa Billa). This represented $<20 \%$ of total $\mathrm{N}$ lost annually from the top layer $(0-0.1 \mathrm{~m}$ depth) of these soils. The $k$ values varied less than the $N_{0}$ values, both within and among soils, and were also less affected by cultivation than $N_{0}$. The mineralizable $\mathrm{N}$ in cultivated soil during cropping for periods up to 70 years can be estimated from $N_{0}$ and $k$ values, taking $N_{0}$ as $5 \%$ of total $\mathrm{N}$ for soils of $<40 \%$ clay and $15 \%$ of total $\mathrm{N}$ for soils of $>40 \%$ clay and $k$ as 0.066 week $^{-1}$ at $40^{\circ} \mathrm{C}\left(0.027\right.$ week $^{-1}$ and 0.054 week $^{-1}$ at $25^{\circ} \mathrm{C}$ and $35^{\circ} \mathrm{C}$, respectively).

Organic $\mathrm{C}$ and $\mathrm{N}$ contained in the 'stabilized' microbial biomass (determined after 30 weeks' pre-incubation) accounted for $1 \cdot 7-3 \cdot 8 \%$ of total organic $C$ and $2 \cdot 0-5 \cdot 1 \%$ of total $N$ in the six soils studied. The microbial biomass $\mathrm{C}$ and $\mathrm{N}$ declined with cultivation in most soils, biomass $\mathrm{N}$ representing $10-23 \%$ of the total annual loss of $N_{0}$. The microbial biomass, urease activity and total $\mathrm{N}$, in addition to a number of other soil properties [e.g. light-fraction $\left(<2 \mathrm{Mg} \mathrm{m}^{-3}\right)$ $\mathrm{C}$, sand-size $\mathrm{C}, \mathrm{CEC}$ and ESP], were significantly correlated with $N_{0}$ and $k$, thus indicating the existence of a myriad of environments for the activity, association and stability of microbial biomass and potentially mineralizable $\mathrm{N}$ in soil.

\section{Introduction}

Cultivation of a soil previously supporting native vegetation or pasture generally leads to a reduction in its organic $\mathrm{C}$ and $\mathrm{N}$ contents. Moreover, the loss of a 'labile' fraction could be proportionately greater than the loss of total soil organic matter (Dalal and Mayer 1986c,1986d), with concomitant diminution of nutrient-supplying capacity, especially $\mathbf{N}$. Factors influencing the ability of soil to supply $\mathrm{N}$ include the amount of mineralizable organic $\mathbf{N}$, the mineralization rate and intensity factors such as moisture and temperature (Campbell et al. 1981).

There are a number of methods used to estimate the $\mathbf{N}$ supplying capacity of soil in the laboratory under constant temperature and moisture conditions (Bremner 1965). Since these methods are empirical in nature, an estimate of relative rather than absolute $\mathbf{N}$ supplying capacity of soil is obtained.

* Part VI, Aust. J. Soil Res., 1987, 25, 83-93. 
Stanford and Smith (1972) used first-order kinetics to describe the net nitrogen mineralized during sequential incubations up to 30 weeks:

$$
N_{t}=N_{0}\{1-\exp (-k t)\} \text {, }
$$

where $N_{t}$ is the cumulative amount of organic $\mathrm{N}$ mineralized $\left(\mathrm{mg} \mathrm{kg}^{-1}\right.$ soil) at time $t$ (weeks), $N_{0}$ is the nitrogen mineralization potential ( $\mathrm{mg} \mathrm{kg}^{-1}$ soil) and $k$ is the mineralization rate constant ( week $^{-1}$ ). They claimed that the nitrogen mineralization potential $\left(N_{0}\right)$, that is, the quantity of soil organic $\mathbf{N}$ that is susceptible to mineralization in the long term according to first-order kinetics, provides an absolute value of $\mathrm{N}$ supplying capacity of soil. For 39 widely different soils, $N_{0}$ varied from 5 to $40 \%$ of total soil N (18-305 mg kg${ }^{-1}$ soil). Campbell et al. (1981) considered $N_{0}$ as an 'active' nitrogen fraction in soil. Since light fraction $\left(<2 \mathrm{Mg} \mathrm{m}^{-3}\right.$ density) and coarse organic matter (mainly sand-size) constitute the labile fractions which are lost rapidly with cultivation (Dalal and Mayer 1986c, 1986d,1987), the objective of this study was to examine the dynamics of $N_{0}$ and its relationship to the labile fractions and other soil properties in six major soils that have been cultivated continuously for cereal cropping for up to 20-70 years. The cultivation effects on the nitrogen mineralization rate constant $(k)$, and the applicability of the model of Jones et al. (1982) to predict $N_{0}$ and $k$ from soil properties were also examined.

Soil microbial biomass, a living part of soil organic matter, is an agent of transformation of the added and native organic matter and a small but labile source as well as a sink of N, P and S (Jenkinson and Ladd 1981). The size of the microbial biomass may, therefore, be related to the amount of potentially mineralizable $\mathrm{N}$ as well as the mineralization rates. This study examined the relationship between $N_{0}$ and $k$ and microbial biomass. The effects of cultivation for periods up to 70 years on the amounts of $\mathrm{C}$ and $\mathbf{N}$ contained in microbial biomass in six soil series are also reported.

\section{Materials and Methods}

The study area (between $27^{\circ}$ and $30^{\circ} \mathrm{S}$. and $148^{\circ}$ and $152^{\circ} \mathrm{E}$.), description of soils, cultural practices, and soil sampling and analytical techniques were described by Dalal and Mayer (1986 $a$, $1986 \mathrm{~b}$ ). The overall range in $\mathrm{pH}$ values, clay and organic $\mathrm{C}$ contents of the six soil series (0-0.1 $\mathrm{m}$ depth) from virgin sites were $6.5-8 \cdot 1,19-74 \%$ and $0.77-2 \cdot 23 \%$, respectively. Soil samples from the top layer $(0-0.1 \mathrm{~m}$ depth) only were used in this study.

Mineralizable $\mathrm{N}$ in soil was measured by the procedure of Stanford and Smith (1972) except that twice the amount of quartz sand was used to increase the rate of leaching because of the high clay content of some of the soils ( $10 \mathrm{~g}$ soil: $20 \mathrm{~g}$ quartz sand). The samples were incubated at $40^{\circ} \mathrm{C}$, assumed to be the optimum temperature for $\mathrm{N}$ mineralization in subtropical soils (Campbell et al. 1981).

Nitrogen mineralization potential $\left(N_{0}, \mathrm{mg} \mathrm{kg}^{-1}\right.$ soil), and mineralization rate constant $(k$, week ${ }^{-1}$ ) were estimated from the measurement of the cumulative $\mathrm{N}$ mineralized $\left(N_{t}\right)$ at time $(t)$ periods of $2,4,8,12,16,22$ and 30 weeks by assuming that organic $N$ was mineralized according to the first-order rate (equation 1). The parameters, $N_{0}$ and $k$ and their standard errors were estimated by a Gauss-Newton iterative regression fitting procedure (Draper and Smith 1966).

The chloroform fumigation procedure of Jenkinson and Powlson (1976) was used to estimate $\mathrm{C}$ and $\mathrm{N}$ contained in microbial biomass. At the end of the incubation period ( 30 weeks) for measurement of mineralizable $\mathrm{N}$, one set of duplicate samples was fumigated with chloroform for $24 \mathrm{~h}$, then both sets were incubated for 10 days at $22^{\circ} \mathrm{C}$, and $\mathrm{CO}_{2}-\mathrm{C}$ evolved over the 10-day period was absorbed in $1 \mathrm{M} \mathrm{NaOH}$ and measured. After 10 days, mineral $\mathrm{N}\left(\mathrm{NH}_{4}^{+}+\mathrm{NO}_{3}^{-}\right)$in the samples was extracted with $2 \mathrm{M} \mathrm{KCl}$ and measured (see Dalal and Mayer 1986a). Further 
incubation for a 10-20 day period was unnecessary because pre-incubated samples were used. The proportion of biomass $\mathrm{C}$ mineralized during the 10-day period after $\mathrm{CHCl}_{3}$ fumigation $\left(k_{\mathrm{C}}\right)$ was taken as 0.41 (Anderson and Domsch 1978), and a $k_{\mathrm{N}}$ value of 0.5 was taken for a rough estimation of biomass $\mathrm{N}$, although the reported $k_{\mathrm{N}}$ values vary from $0.2-0.3$ (Voroney and Paul 1984) to 0.68 (Shen et al. 1984).

All results were expressed on an oven-dry soil weight basis $\left(105^{\circ} \mathrm{C}\right)$. Since the bulk density of soils changed due to cultivation, corrections in mineralizable $\mathrm{N}$ and microbial biomass $\mathrm{C}$ and $\mathrm{N}$ were made for equivalent soil depth among a soil series, similar to the proportionate changes in organic C and N (Dalal and Mayer 1986 b, 1986e).

Table 1. Nitrogen mineralization potential $\left(N_{0}\right), N_{0} /$ total $\mathbf{N}$ and mineralization rate constant $(k)$

Mean \pm s.d. values from virgin sites

\begin{tabular}{lccc}
\hline $\begin{array}{c}\text { Soil series } \\
(\text { No. of soils) }\end{array}$ & $\begin{array}{c}N_{0} \\
\left(\mathrm{mg} \mathrm{kg}^{-1} \text { soil) }\right.\end{array}$ & $\begin{array}{c}N_{0} / \text { total N } \\
(\%)\end{array}$ & $\begin{array}{c}k \\
\text { (week }^{-1} \text { ) }\end{array}$ \\
\hline Waco (5) & $203 \pm 8$ & $14 \pm 1$ & $0.050 \pm 0.017$ \\
Langlands-Logie (6) $^{\mathrm{B}}$ & $217 \pm 55$ & $11 \pm 3$ & $0.075 \pm 0.029$ \\
Cecilvale (7) $^{\mathrm{B}}$ & $197 \pm 45$ & $15 \pm 3$ & $0.078 \pm 0.030$ \\
Billa Billa (7) & $180 \pm 33$ & $13 \pm 2$ & $0.063 \pm 0.026$ \\
Thallon (6) $^{\mathrm{B}}$ & $151 \pm 98$ & $23 \pm 15$ & $0.052 \pm 0.025$ \\
Riverview (5) $^{\mathrm{C}}$ & $110 \pm 22$ & $13 \pm 3$ & $0.051 \pm 0.023$ \\
\hline
\end{tabular}

A Black earth (Typic Pellusterts).

B Grey, brown and red clays (brigalow, poplar box, belah and coolibah vegetation, respectively) (Typic Chromusterts).

C Red earth (Rhodic Paleustalfs).

\section{Results and Discussion}

\section{Nitrogen Mineralization Potentials $\left(N_{0}\right)$ and Mineralization Rate Constants $(k)$ in Virgin Soils}

The $N_{0}$ values varied from $110 \mathrm{mg} \mathrm{kg}^{-1}$ soil (range, $79-140 \mathrm{mg} \mathrm{kg}^{-1}$ soil) in Riverview soil to $217 \mathrm{mg} \mathrm{kg}^{-1}$ soil (146-290 $\mathrm{mg} \mathrm{kg}^{-1}$ soil) in Langlands-Logie soil (Table 1). Campbell et al. (1981) estimated similar $N_{0}$ values for five Queensland soils. These values are also within the range of mean values $\left(110-270 \mathrm{mg} \mathrm{kg}^{-1}\right.$ soil) reported for seven soil orders (Jones et al. 1982). Although $N_{0}$ values for red earths (Riverview) were lower than the other five soil series (vertisols), $N_{0} /$ total $\mathrm{N}$ per cent ('active' N) was not significantly different from other soils (Table 1). Similarly, $k$ values did not differ significantly among the six soil series. The mean $k$ value $\left(0.066 \pm 0.028\right.$ week $^{-1}$ at $\left.40^{\circ} \mathrm{C}\right)$ for all virgin soils $(n=36)$ was similar to those obtained by Campbell et al. (1981) and Stanford and Smith (1972) (0.070 and 0.066 week ${ }^{-1}$ at $40^{\circ} \mathrm{C}$ respectively). The $\mathrm{N}$ mineralization rate, therefore, is essentially similar in arable soils under similar temperature and moisture conditions.

The cumulative amounts of mineralized $\mathrm{N}\left(N_{t}\right)$ as proportions of $N_{0}$ at 2, 4, 8, $12,16,22$ and 30 weeks' incubation were $0.39,0.48,0.58,0.67,0.74,0.80$ and 0.86 , respectively; the relationship between $N_{t}$ and $N_{0}$ became closer as the period of incubation increased. This was also observed by Stanford and Smith (1972). On this basis, Stanford et al. (1974) suggested that estimates of $N_{0}$ may be obtained from $\mathrm{N}$ mineralized during 2-week incubations following preliminary incubations of 1-2 weeks. From such a relationship, however, only poor estimates of $N_{0}$ would be obtained from short-term incubations in all soils, since in cultivated soils, the 
relationships between $N_{t}$ and $N_{0}$ were much lower $(r<0.7)$, even up to 16 weeks of incubation.

Soil properties that were significantly associated with $N_{0}$ (using stepwise multiple regression analysis) were oxalate-extractable iron $\left(\mathrm{Fe}_{\mathrm{o}}\right.$ ) and total $\mathrm{N}(\mathrm{TN})$ in virgin soils $\left(R^{2}=0.76\right)$, that is,

$$
N_{0}=45+168 * * \mathrm{Fe}_{\circ}(\%)+735 * * * \mathrm{TN}(\%) .
$$

Total $\mathrm{N}$ accounted for most of the variation $\left(R^{2}=0.70\right)$ in $N_{0}$. Stanford and Smith (1972) also obtained a close relationship between $N_{0}$ and total $\mathrm{N}\left(R^{2}=0.66\right) . \mathrm{Fe}_{\mathrm{o}}$ in soil is involved in aggregation, probably through organic matter and clay bonding, and thus could affect $N_{0}$ by modifying the physical environment in which microorganisms function and have access to mineralizable $\mathrm{N}$.

The mineralization rate constant $(k)$ in virgin soils was significantly correlated with urease activity $\left(r=0.34^{*}\right)$ and microbial biomass $C\left(r=0.47^{*}\right)$, and hence may be regulated by microbial biomass and biochemical activity in soil.

Table 2. Microbial biomass $\mathrm{C}$ (MB-C) and microbial biomass $\mathrm{N}$ (MB-N) Mean \pm s.d. values from virgin sites

\begin{tabular}{lcccc}
\hline $\begin{array}{c}\text { Soil } \\
\text { series }\end{array}$ & $\begin{array}{c}\text { MB-C } \\
\left(\mathrm{mg} \mathrm{kg}^{-1} \text { soil) }\right.\end{array}$ & $\begin{array}{c}\text { MB-C/organic C } \\
(\%)\end{array}$ & $\begin{array}{c}\text { MB-N } \\
\left(\mathrm{mg} \mathrm{kg}^{-1} \text { soil) }\right.\end{array}$ & $\begin{array}{c}\text { MB-N/total N } \\
(\%)\end{array}$ \\
\hline Waco & $453 \pm 137$ & $2 \cdot 8 \pm 0 \cdot 8$ & $52 \pm 10$ & $3 \cdot 5 \pm 0 \cdot 7$ \\
Langlands-Logie & $508 \pm 253$ & $2 \cdot 3 \pm 1 \cdot 1$ & $47 \pm 16$ & $2 \cdot 3 \pm 0 \cdot 8$ \\
Cecilvale & $464 \pm 53$ & $2 \cdot 7 \pm 0 \cdot 3$ & $35 \pm 6$ & $2 \cdot 7 \pm 0 \cdot 4$ \\
Billa Billa & $361 \pm 91$ & $2 \cdot 4 \pm 0 \cdot 6$ & $29 \pm 4$ & $2 \cdot 0 \pm 0 \cdot 3$ \\
Thallon & $291 \pm 62$ & $3 \cdot 8 \pm 0 \cdot 8$ & $33 \pm 15$ & $5 \cdot 1 \pm 2 \cdot 3$ \\
Riverview & $213 \pm 52$ & $1.7 \pm 0 \cdot 4$ & $22 \pm 7$ & $2 \cdot 5 \pm 0 \cdot 8$ \\
\hline
\end{tabular}

\section{Microbial Biomass $C(M B-C)$ and Microbial Biomass $N(M B-N)$ in Virgin Soils}

The distribution of MB-C and MB-N was similar to $N_{0}$ among the soil series (Table 2). On soil volume basis (using bulk density values from Dalal and Mayer 1986a), Riverview soil contained the lowest amounts of MB-C and MB-N (264 and $27 \mathrm{~kg} \mathrm{ha}^{-1} \mathrm{dm}^{-1}$ ) and Langlands-Logie soil contained the highest amounts of MB-C and MB-N (503 and $47 \mathrm{~kg} \mathrm{ha}^{-1} \mathrm{dm}^{-1}$ ). The Langlands-Logie soil also contained the highest amounts of organic $\mathrm{C}$ and total $\mathrm{N}$ among the six soil series studied (Dalal and Mayer $1986 b, 1986 e$ ).

The proportions of soil organic C contained in MB-C (1.7-3.8\%) of these six soils from virgin sites are similar to those observed in South Australian soils carrying improved pastures (Oades and Jenkinson 1979) and fall within the range of MB-C values reported in soils from different climatic regions (Jenkinson and Ladd 1981; McGill et al. 1986). Also, MB-N values, which varied from 2.0 to $5.1 \%$ of the total soil N, are similar to those reported elsewhere (Jenkinson and Ladd 1981). However, the $C: N$ ratio of the microbial biomass was almost twice that reported in many studies $(8 \cdot 7-13 \cdot 2$; mean, 10.6), and approached that of the whole soil, probably representing that of 'stabilized' microbial biomass. The $\mathrm{C}: \mathbf{N}$ ratios of the microbial biomass reported in the literature are not always comparable because the proportion of microbial biomass $\mathrm{N}$ mineralized after fumigation and 10 days' incubation, $k_{\mathrm{N}}$, varies from 0.2-0.3 (Voroney and Paul 1984) to 0.68 (Shen et al. 1984). Admittedly, 
some proportion of the microbial biomass may have been mineralized during the pre-incubation period before the soil was fumigated. The MB-C and MB-N values reported in this study may, therefore, be taken as relative values only, which are used for comparative purposes here.

The MB-C was negatively correlated with the mean annual temperature $(r=$ $\left.-0.84^{*}\right)$ of the six soil series, but positively with the rainfall $(r=0.71 \mathrm{NS})$. Both MB-C and MB-N were significantly correlated with the urease activity ( $r$ values, $0.77^{* *}$ and $0.68^{* *}$, respectively) of the virgin soils $(n=36)$. Thus biological and biochemical activity of the soils are interrelated.

\section{Dynamics of $N_{0}$ and $k$ in Cultivated Soils}

The relationships between mineralizable $N$ measured from the cumulative net mineralized $\mathrm{N}$ over $2-30$ weeks, the derived values of nitrogen mineralization potential $\left(N_{0}\right)$ or mineralization rate $(k)$ and period of cultivation $(t)$ were described according to the exponential equation:

$$
Y_{t}=Y_{\mathrm{e}}+\left(Y_{0}-Y_{\mathrm{e}}\right) \exp (-r t)
$$

where $Y$ represents mineralizable $\mathrm{N}, N_{0}$ or $k ; Y_{0}, Y_{t}$ and $Y_{\mathrm{e}}$ represent values initially $(t=0)$, at time $t$ (years) and at equilibrium $(t \rightarrow \infty)$, respectively; $r$ is the rate of loss $\left(\right.$ year $\left.^{-1}\right)$.

Table 3. Initial values ( $\left.Y_{0}\right)$, equilibrium values $\left(Y_{\mathrm{e}}\right)$, rate of loss $(r)$ and half-life of loss $\left(t_{1 / 2}\right)$ of mineralizable $\mathbf{N}$ and nitrogen potential $\left(N_{0}\right)$ after different incubation periods in Waco soil cultivated for 0-70 years

$Y_{0}, Y_{\mathrm{e}}$ and $r$ were calculated according to equation (3); the half-life, $t_{1 / 2}=\ln 2 / r$

\begin{tabular}{|c|c|c|c|c|c|}
\hline $\begin{array}{l}\text { Period of } \\
\text { incubation } \\
\text { (weeks) }\end{array}$ & $\begin{array}{c}Y_{0} \\
\text { mean } \pm \text { s.e. } \\
\left(\mathrm{mg} \mathrm{kg}{ }^{-1} \text { soil) }\right.\end{array}$ & $\begin{array}{c}Y_{\mathrm{e}} \\
\text { mean } \pm \text { s.e. } \\
\left(\mathrm{mg} \mathrm{kg}^{-1} \text { soil }\right)\end{array}$ & $\begin{array}{c}r \\
\text { mean } \pm \text { s.e. } \\
\left(\text { year }^{-1}\right)\end{array}$ & $\begin{array}{c}t_{1 / 2} \\
\text { mean } \pm \text { s.e. } \\
\quad \text { (year) }\end{array}$ & $R^{2}$ \\
\hline 2 & $86 \pm 7$ & $24 \pm 5$ & $0.334 \pm 0.157$ & $2 \pm 1$ & 0.75 \\
\hline 4 & $103 \pm 7$ & $35 \pm 6$ & $0.208 \pm 0.092$ & $3 \pm 1$ & 0.77 \\
\hline 8 & $121 \pm 8$ & $43 \pm 10$ & $0.075 \pm 0.034$ & $9 \pm 4$ & 0.76 \\
\hline 12 & $136 \pm 7$ & $49 \pm 15$ & $0.052 \pm 0.024$ & $13 \pm 6$ & 0.78 \\
\hline 16 & $149 \pm 8$ & $57 \pm 16$ & $0.051 \pm 0.024$ & $14 \pm 6$ & 0.77 \\
\hline 22 & $165 \pm 8$ & $65 \pm 15$ & $0.054 \pm 0.023$ & $13 \pm 6$ & 0.80 \\
\hline 30 & $181 \pm 8$ & $73 \pm 16$ & $0.056 \pm 0.024$ & $12 \pm 5$ & 0.80 \\
\hline$N_{0} \mathrm{~A}$ & $208 \pm 9$ & $90 \pm 10$ & $0.090 \pm 0.029$ & $8 \pm 3$ & 0.85 \\
\hline
\end{tabular}

A $N_{0}$ was calculated according to equation (1).

Where the rate of loss, $r$, was not significant (standard errors estimated according to Draper and Smith 1966) at $P<0.05$, a linear regression was used to describe the relationships between mineralizable $\mathrm{N}, N_{0}$ or $k\left(Y_{t}\right)$ and period of cultivation $(t)$ :

$$
Y_{t}=Y_{0}-a_{1} t
$$

where $a_{1}$ is the regression coefficient. The kinetic parameters (equation 3 ) of mineralizable $\mathrm{N}$ and $N_{0}$ in Waco soil (0-0.1 m depth) are given in Table 3 and the relationship between $N_{0}$ and period of cultivation is shown in Fig. 1. 
The rate of loss of the mineralizable $\mathbf{N}$ decreased as the period of incubation increased, especially during the short 2-8 weeks' incubation periods (Table 3). Conversely, the half-life, $t_{1 / 2}$, of the mineralizable $\mathbf{N}$ increased from 2 years at 2 weeks' incubation to 13 years at 12 weeks' incubation. Obviously soil contains various forms of organic $\mathbf{N}$ that differ in the rates of mineralization, for example, $\mathrm{N}$ contained in different particle-size and density fractions (Dalal and Mayer 1987) and/or MB-N in various microflora and fauna in soil. It is for this reason that equation (1) represents an oversimplification of mineralization rates. However, an attempt to describe the mineralization rates with two fractions, such as the light fraction $\left(<2 \mathrm{Mg} \mathrm{m}^{-3}\right.$ ) and the heavy fraction $\left(>2 \mathrm{Mg} \mathrm{m}^{-3}\right.$ ) (Dalal and Mayer $1986 \mathrm{~d}$, 1987), was successful only in a few soil samples, although Deans et al. (1986) found that a double exponential equation provided a better fit than the single exponential equation (1).

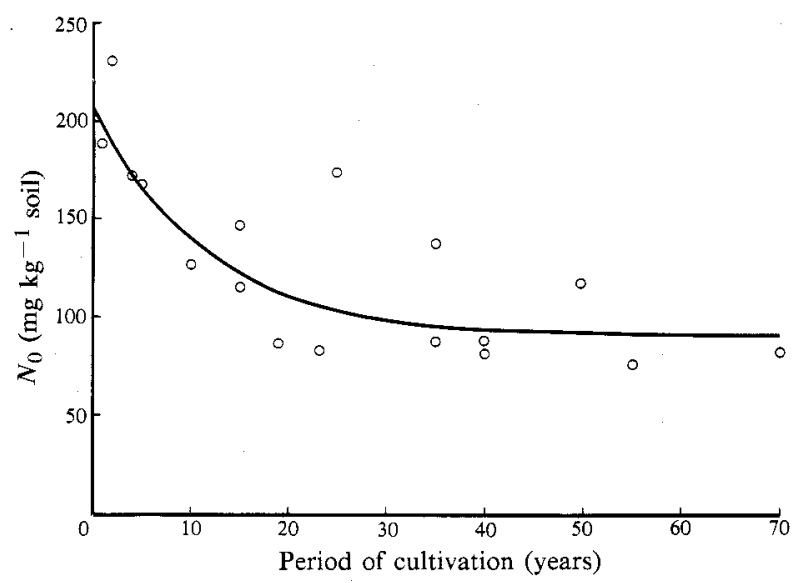

Fig. 1. Relationship between nitrogen mineralization potentials $\left(N_{0}\right)$ and period of cultivation in Waco soil. The curve is fitted according to equation (3).

In the present study, the apparent failure of the double exponential equation

$$
N_{t}=N_{0} S\{1-\exp (-h t)\}+N_{0}(1-S)\{1-\exp (-k t)\},
$$

where $S$ and $(1-S)$ represent the labile and the resistant organic $\mathbf{N}$ fractions that mineralize at rate constants of $h$ and $k$, respectively, may be because either insufficient mineralization data at short-incubation periods were available or there are more than two fractions of organic $\mathrm{N}$ that contribute to $N_{0}$ (Richter et al. 1982). The latter is supported by the $r$ values obtained for the Waco soil (Table 3). For example, the rate of loss due to cultivation of mineralizable $\mathrm{N}$ measured after 2 weeks' incubation $\left(0.33 \mathrm{yr}^{-1}\right)$ was similar to that of organic $\mathrm{C}$ in the light fraction $\left(0.37 \mathrm{yr}^{-1}\right.$; Dalal and Mayer $1986 \mathrm{~d})$, and that after 4 weeks' incubation $\left(0.21 \mathrm{yr}^{-1}\right)$ was similar to that of organic $\mathrm{N}$ in the light fraction $\left(0.19 \mathrm{yr}^{-1}\right.$; Dalal and Mayer 1987), and that after 8 weeks' incubation $\left(0.08 \mathrm{yr}^{-1}\right)$ was similar to that of sand-size organic $\mathrm{N}$ $\left(0.09 \mathrm{yr}^{-1}\right.$; Dalal and Mayer 1986d). The rate loss of mineralizable $\mathrm{N}$ after 12-30 weeks' incubation $\left(0.05-0.06 \mathrm{yr}^{-1}\right)$ was similar to that of total $\mathrm{N}\left(0.06 \mathrm{yr}^{-1}\right.$; Dalal and Mayer 1986e) in this soil. The $N_{0}$ in soil represents, therefore, a number of organic matter fractions of differing mineralization rates. 
In the other five soils, rates of loss of mineralizable $\mathbf{N}$ after different periods of incubation and of nitrogen mineralization potentials $\left(N_{0}\right)$ were linear with the period of cultivation (Table 4). The loss of $N_{0}$ accounted for less than $20 \%$ of the annual rate of loss of total $\mathrm{N}$ from the equivalent depth $(0-0.1 \mathrm{~m})$ of these six soils (R. C. Dalal, unpublished data). Since annual loss of total $\mathbf{N}$ from these soils was primarily accounted for in the crop removal (Dalal and Mayer 1986e), it is obvious that $\mathrm{N}$ supply to crops originated from other organic $\mathrm{N}$ fractions in addition to those contributing mineralizable $\mathrm{N}$ to $N_{0}$ under laboratory conditions. This was also reflected in the fact that, in five of the six soil series, $N_{0}$ declined with cultivation at a rate similar to that of total $\mathrm{N}$. Only in Billa Billa soil, $N_{0}$ declined faster than the total N. In the majority of these soils, therefore, $N_{0}$ did not provide a significantly more sensitive index of soil fertility degradation due to cultivation than that shown by total soil $\mathbf{N}$ loss.

Table 4. Annual rate of loss ( \pm s.e.) of mineralizable $\mathbf{N}$ (after 2 and 30 weeks' incubation) and nitrogen mineralization potential $\left(N_{0}\right)$ from six soils

NS, not significant; all other values were significant at $P<0.05$

\begin{tabular}{|c|c|c|c|c|}
\hline \multirow[t]{2}{*}{$\begin{array}{l}\text { Soil } \\
\text { series }\end{array}$} & \multirow{2}{*}{$\begin{array}{l}\text { Period of } \\
\text { cultivation } \\
\text { (years) }\end{array}$} & \multicolumn{3}{|c|}{$\begin{array}{l}\text { Rate of loss }\left(\mathrm{mg} \mathrm{N} \mathrm{kg}^{-1} \text { soil } \mathrm{yr}^{-1}\right)^{\mathrm{A}} \\
\text { Mineralizable } \mathrm{N}\end{array}$} \\
\hline & & 2 weeks & 30 weeks & \\
\hline $\mathrm{Waco}^{\mathrm{B}}$ & $1-70$ & $0.9 \pm 0.3$ & $1.8 \pm 0.3$ & $2 \cdot 0 \pm 0.3$ \\
\hline Langlands-Logie & $0 \cdot 5-45$ & $1 \cdot 3 \pm 0 \cdot 3$ & $4.0 \pm 0.7$ & $4 \cdot 2 \pm 0.8$ \\
\hline Cecilvale & $3-35$ & $0.9 \pm 0.2$ & $2.6 \pm 0.7$ & $2 \cdot 6 \pm 0.7^{C}$ \\
\hline Billa Billa & $0 \cdot 5-25$ & $1.9 \pm 0.3$ & $4 \cdot 5 \pm 0 \cdot 5$ & $4 \cdot 8 \pm 2 \cdot 0^{\mathrm{C}}$ \\
\hline Thallon & $2-23$ & $0.6 \pm 0.1$ & $1 \cdot 7 \pm 0.3$ & $1.8 \pm 0.5^{\mathrm{C}}$ \\
\hline Riverview & $0 \cdot 5-20$ & NS & NS & $1.7 \pm 0.5^{\mathrm{C}}$ \\
\hline
\end{tabular}

A Calculated according to equation (4) where $a_{1}$ represents the rate of loss.

B For Waco soil, rates of loss of mineralizable $\mathrm{N}$ and $N_{0}$ were calculated according to equation (4) for comparative purposes only.

C Excluding 1-2 samples of large $N_{0}$ values (exceeding twice that of mineralizable $\mathrm{N}$ after 30 weeks' incubation).

The poor sensitivity of nitrogen mineralization potential $\left(N_{0}\right)$ to soil fertility degradation may be due, at least, to two reasons. One reason is that during preliminary leaching, organic $\mathbf{N}$, that may otherwise have been mineralized during incubation, was lost from the soil. Moreover, solutions leached through incubated soil samples contain organic $\mathrm{N}$ compounds which may be readily mineralizable (Legg et al. 1971). For example, Smith et al. (1980) found that amounts of organic $\mathrm{N}$ leached during 11 weeks' incubation in three soils ranged from $13 \%$ to $163 \%$ of total mineralized $\mathbf{N}$. Another reason is that mineralizable $\mathbf{N}$ was measured under constant soil moisture and temperature conditions, whereas in the field, under semiarid and subtropical conditions, wetting and drying of soil occur frequently. This would result in disruption of aggregates and exposure of new surfaces, thus making available additional mineralizable $\mathrm{N}$ which otherwise would have been inaccessible to microorganisms. Frequent wetting and drying and fluctuating temperatures also affect the activity, stability and mortality of microbial biomass and change the solubility of soil organic $\mathbf{N}$. 
The mineralization rate constant, $k$, was not significantly affected by the period of cultivation in Waco, Langlands-Logie, Thallon and Riverview soils, although in Cecilvale and Billa Billa soils it decreased with the period of cultivation. In these two soils, therefore, a greater loss of rapidly mineralizable organic $\mathrm{N}$ occurred, resulting in reduced $k$ values with increasing period of cultivation.

The soil properties significantly associated with $N_{0}$ of both cultivated and virgin soils (using stepwise multiple linear regression analysis) were total $\mathrm{N}$ or organic $\mathrm{C}$, clay content, electrical conductivity, light fraction $\left(<2 \mathrm{Mg} \mathrm{m}^{-3}\right) \mathrm{C}$ content, silt-size $\mathrm{C}$, sand-size C, CEC, ESP and aggregate index, which together accounted for $74 \%$ of the variation in $N_{0}$. Of this, total $\mathrm{N}$ alone accounted for $60 \%$ of the variation in $N_{0}$. The relationship between $N_{0}$ and total $\mathbf{N}$ of six soil series is shown in Fig. 2.

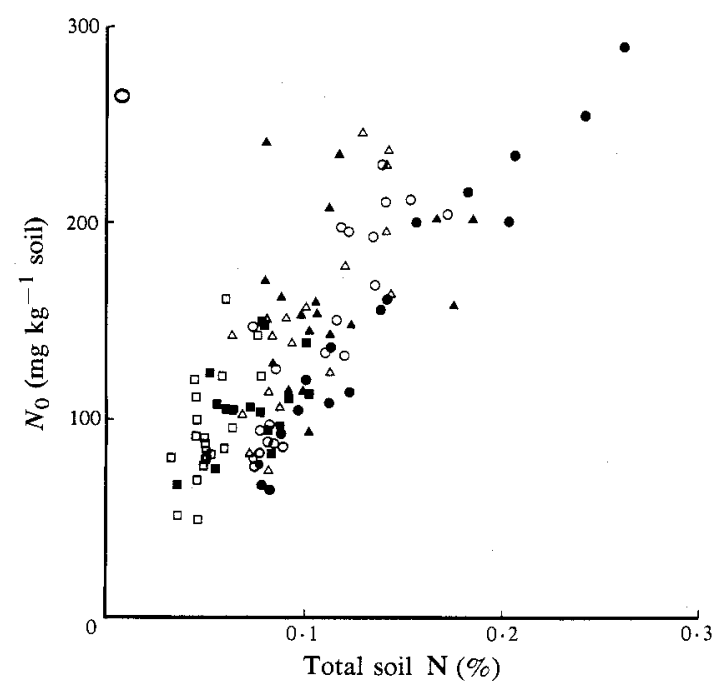

Fig. 2. Relationship between nitrogen mineralization potentials $\left(N_{0}\right)$ and total

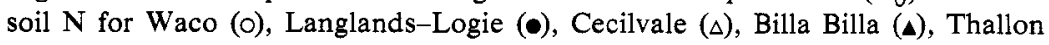
() and Riverview (E) soils.

The equation between $N_{0}$ and total $\mathrm{N}$,

$$
N_{0}=43+970 \mathrm{TN}(\%), \quad r=0.78 * * \quad(n=110),
$$

shows that overall about $10 \%$ of total $\mathrm{N}$ is present as $N_{0}$ in these soils. However, there were significant differences among soils. The cultivated lighter-textured soils $(<40 \%$ clay) contributed less than $10 \%$ to total N (Billa Billa, 5.20 $2 \cdot 31 \%$; Riverview, $6.08 \pm 2.31 \%)$ and heavy-textured soils $(>40 \%$ clay) contributed more than $10 \%$ to total $\mathbf{N}$ (Langlands-Logie, $11.62 \pm 0.65 \%$; Cecilvale, $14.39 \pm 2.79 \%$; Waco, $15 \cdot 18 \pm 1 \cdot 89 \%$; and Thallon, $14 \cdot 38 \pm 4 \cdot 61 \%$ ). Thus, although the lighter-textured soils in their virgin state contained proportions of total $\mathrm{N}$ as $N_{0}$ similar to the heavy-textured soils (Table 1), upon cultivation, lower values in the former reflect relatively less potentially mineralizable $\mathbf{N}$ in these soils.

Jones et al. (1982) used total $\mathrm{N}$, organic $\mathrm{C}, \mathrm{pH}$ and soil taxonomic criteria to estimate $N_{0}$ in soils. In these soils, however, the relationship between the experimental values of $N_{0}$ and the predicted $N_{0}$ values gave a lower correlation $\left(r=0.70^{* *}\right.$, 
$n=110$ ) than that provided by total soil $\mathrm{N}$ alone. Moreover, the mineralization rate constant, $k$, could not be predicted $\left(r^{2}=0.05\right)$ using the model of Jones et al. (1982). This is not surprising considering the fact that the $k$ values were poorly, although significantly correlated with total $\mathrm{N}\left(r=0.19^{*}\right)$, organic $\mathrm{C}\left(r=0.22^{*}\right)$ and $\mathrm{pH}\left(r=0 \cdot 23^{*}\right)$, i.e. the soil properties used by Jones et al. (1982) to predict the $k$ value.

The $k$ values were significantly associated (using stepwise multiple linear regression analysis) with electrical conductivity, light fraction $\mathrm{C}$ concentration, cation exchange capacity, ESP, oxalate extractable aluminium, dispersion ratio, clay-size $\mathrm{N}$, sand-size $\mathrm{N}$ and MB-C. The combination of these soil properties explained less than $40 \%$ of the variation in $k$, mainly because $k$ varied much less than the other properties both within and among soils. Thus the $k$ value of 0.066 week $^{-1}$ at $40^{\circ} \mathrm{C}$ (present study) and 0.054 week $^{-1}$ at $35^{\circ} \mathrm{C}$ (Stanford and Smith 1972) can be used, along with $N_{0}$ and the relationship between temperature and moisture contents and $N_{0}$ (Smith et al. 1977), to provide approximate mineralization rates under field conditions.

Table 5. Annual rate of loss ( \pm s.e.) of $\mathrm{C}$ and $\mathbf{N}$ contained in microbial biomass (MB-C and MB-N) from six soils

NS, not significant; all other values were significant at $P<0.05$

\begin{tabular}{|c|c|c|}
\hline \multirow{2}{*}{$\begin{array}{l}\text { Soil } \\
\text { series }\end{array}$} & \multicolumn{2}{|c|}{ Rate of loss ${ }^{A}$} \\
\hline & $\frac{\mathrm{MB}-\mathrm{C}}{\left(\mathrm{mg} \mathrm{C} \mathrm{kg}^{-1} \text { soil } \mathrm{yr}^{-1}\right)}$ & $\begin{array}{c}\text { MB-N } \\
\left(\mathrm{mg} \mathrm{N} \mathrm{kg}^{-1} \text { soil } \mathrm{yr}^{-1}\right)\end{array}$ \\
\hline Waco & $4 \cdot 4 \pm 1 \cdot 5$ & $0.21 \pm 0.08$ \\
\hline Langlands-Logie & $14 \cdot 3 \pm 3 \cdot 5$ & $0.53 \pm 0.10$ \\
\hline Cecilvale & $7 \cdot 5 \pm 1 \cdot 7$ & $0.32 \pm 0.07$ \\
\hline Billa Billa & $6 \cdot 3 \pm 2 \cdot 4$ & $0.48 \pm 0.09^{B}$ \\
\hline Thallon & NS & NS \\
\hline Riverview & NS & $0.39 \pm 0.19$ \\
\hline
\end{tabular}

\section{Dynamics of Microbial Biomass in Cultivated Soils}

The organic $\mathrm{C}$ and $\mathrm{N}$ contained in microbial biomass declined linearly with the period of cultivation (20-70 years) in most soils. In Thallon soil, microbial biomass was not significantly related to the period of cultivation. Both MB-C and MB-N declined most in the Langlands-Logie soil and least in the Waco soil (Table 5). The proportion of MB-N lost due to cultivation represented 10-23\% of annual $N_{0}$ loss, and less than $5 \%$ of total soil $\mathbf{N}$ loss. In Billa Billa soil, where MB-N was lost exponentially, MB-N showed a high rate of loss $\left(0.338 \mathrm{yr}^{-1}\right)$, with a half-life of 2.1 years (Table 5), a rate of loss similar to that of the light fraction $\mathrm{C}(0.42$ week $^{-1}$ ) in this soil (Dalal and Mayer 1986d). Adams and Laughlin (1981) also found lower macroorganic matter and microbial biomass $\mathrm{C}$ and $\mathrm{N}$ in cultivated soil than in grassland or woodland soils. Similarly, Ladd et al. (1977) showed that the destruction of soil biomass was accompanied by significant decreases in the organic $\mathrm{N}$ of a light fraction from straw-amended soils. The half-life of 2.1 years for MB-N in Billa Billa soil is similar to the 'stabilized' microbial biomass in soil (Jenkinson and Ladd 1981; McGill et al. 1986). 
A number of soil properties was associated with the microbial biomass (Table 6). The linear combination of urease activity, sand-size organic $\mathrm{C}$, exchangeable $\mathrm{Ca}$ and $\mathrm{Fe}_{\mathrm{o}}$ explained $52 \%$ variation in the MB-C. In the MB-N, $64 \%$ of the variation was accounted for by the linear combination of total $\mathrm{N}$, clay-size organic $\mathrm{C}$, exchangeable $\mathrm{Mg}, \mathrm{CEC}, \mathrm{ESP}, \mathrm{Fe}_{\mathrm{o}}$ and MB-C. The association of a number of soil properties, biochemical, physical as well as chemical, with the microbial biomass provide a myriad of environments for its activity, association and stability in soil.

Table 6. Coefficients of correlation between microbial biomass (MB-C and MB-N) and some soil properties

Only significant $r$ values $(P<0.05, n=110)$ are given

\begin{tabular}{|c|c|c|c|c|c|}
\hline Soil property & MB-C & MB-N & Soil property & MB-C & MB-N \\
\hline Organic C (\%) & 0.55 & 0.51 & Exch. $\mathrm{Ca}$ & & 0.46 \\
\hline Light fraction $\mathrm{C}(\%)$ & 0.28 & & Exch. $\mathrm{Mg}$ & & 0.56 \\
\hline Clay-C (\%) & & -0.22 & Exch. $\mathrm{Na}$ & & 0.25 \\
\hline Silt-C (\%) & 0.28 & 0.39 & Exch. $\mathrm{K}$ & & 0.38 \\
\hline Sand-C $(\%)$ & 0.46 & 0.62 & Oxalate-extractable $\mathrm{Fe}\left(\mathrm{Fe}_{\mathrm{o}}\right)$ & 0.43 & 0.56 \\
\hline Total N (\%) & 0.53 & 0.47 & Aggregate index & 0.19 & 0.28 \\
\hline Light fraction $\mathbf{N}(\%)$ & 0.32 & & $\mathrm{pH}$ & & 0.23 \\
\hline Silt-N $(\%)$ & & $0 \cdot 30$ & $\mathrm{EC}$ & 0.21 & 0.23 \\
\hline Sand-N (\%) & 0.38 & 0.51 & Nitrogen min. potential, $N_{0}$ & 0.43 & 0.38 \\
\hline Urease activity & 0.58 & 0.47 & Mineralization rate, $k$ & 0.36 & 0.21 \\
\hline Clay $(\%)$ & & 0.48 & $\mathrm{MB}-\mathrm{C}$ & & 0.51 \\
\hline CEC & 0.22 & 0.56 & & & \\
\hline
\end{tabular}

\section{Conclusions}

Mineralizable N, measured after 2-30 weeks' incubation, and nitrogen mineralization potential $\left(N_{0}\right)$ decreased with cultivation in most soils. The shorter the period of incubation for measuring mineralizable $\mathrm{N}$, the faster was its estimated rate of loss due to cultivation. Hence, the relative susceptibility to mineralization decreases as the period of incubation increases because less labile organic $\mathbf{N}$ is being used. The $N_{0}$ represents, therefore, soil organic $\mathrm{N}$ fractions which differ in their susceptibility to mineralization. The mineralization rate constant, $k$, appears to be less affected by cultivation and, for the purpose of predicting $\mathbf{N}$ mineralization rates in soil in the field, it can be taken as a constant $\left(0.054\right.$ and 0.066 week ${ }^{-1}$ at $35^{\circ} \mathrm{C}$ and $40^{\circ} \mathrm{C}$, respectively). The $N_{0}$, as a proportion of total $\mathrm{N}$, in cultivated soils, which varies from $5 \%$ (light-textured soils, $<40 \%$ clay) to $15 \%$ (heavy-textured soils, $>40 \%$ clay) of total $\mathrm{N}$, may improve estimates of mineralizable $\mathbf{N}$ in different soils, although $10 \%$ as $N_{0}$ /total $\mathrm{N}$ may provide an approximate estimate of $N_{0}$ in southern Queensland soils.

Organic $\mathbf{C}$ and $\mathbf{N}$ contained in microbial biomass decreased with the period of cultivation in most soils. The size of the microbial biomass, urease activity and total $\mathbf{N}$, among other soil properties, were associated with $N_{0}$ and $k$, thus demonstrating the biological and biochemical interactions in soil.

\section{Acknowledgment}

We thank Dr J. P. Thompson for critical comments and suggestions. 


\section{References}

Adams, T. McM., and Laughlin, R. J. (1981). The effects of agronomy on the carbon and nitrogen contained in the soil biomass. J. Agric. Sci. 97, 319-27.

Anderson, J. P. E., and Domsch, K. H. (1978). Mineralization of bacteria and fungi in chloroform-fumigated soils. Soil Biol. Biochem. 10, 207-13.

Bremner, J. M. (1965). Nitrogen availability indexes. In 'Methods of Soil Analysis, Part 2'. (Ed. C. A. Black.) pp. 1324-45. (Am. Soc. Agron.: Madison, Wisc.)

Campbell, C. A., Myers, R. J. K., and Weier, K. L. (1981). Potentially mineralizable nitrogen, decomposition rates and their relationship to temperature for five Queensland soils. Aust. $J$. Soil Res. 19, 323-32.

Dalal, R. C., and Mayer, R. J. (1986a). Long-term trends in fertility of soils under continuous cultivation and cereal cropping in southern Queensland. I. Overall changes in soil properties and trends in winter cereal yields. Aust. J. Soil Res. 24, 265-79.

Dalal, R. C., and Mayer, R. J. (1986 b). Long-term trends in fertility of soils under continuous cultivation and cereal cropping in southern Queensland. II. Total organic carbon and its rate of loss from the soil profile. Aust. J. Soil Res. 24, 281-92.

Dalal, R. C., and Mayer, R. J. (1986c). Long-term trends in fertility of soils under continuous cultivation and cereal cropping in southern Queensland. III. Distribution and kinetics of soil organic carbon in particle-size fractions. Aust. J. Soil Res. 24, 293-300.

Dalal, R. C., and Mayer, R. J. (1986d). Long-term trends in fertility of soils under continuous cultivation and cereal cropping in southern Queensland. IV. Loss of organic carbon from different density fractions. Aust. J. Soil Res. 24, 301-9.

Dalal, R. C., and Mayer, R. J. (1986e). Long-term trends in fertility of soils under continuous cultivation and cereal cropping in southern Queensiand. V. Rate of loss of total nitrogen from the soil profile and changes in carbon-nitrogen ratios. Aust. J. Soil Res. 24, 493-504.

Dalal, R. C., and Mayer, R. J. (1987). Long-term trends in fertility of soils under continuous cultivation and cereal cropping in southern Queensland. VI. Loss of total $\mathrm{N}$ from different particle-size fractions. Aust. J. Soil Res. 25, 83-93.

Deans, J. R., Molina, J. A. E., and Clapp, C. E. (1986). Models for predicting potentially mineralizable nitrogen and decomposition rate constants. Soil Sci. Soc. Am. J. 50, 323-6.

Draper, N. R., and Smith, H. (1966). 'Applied Regression Analysis.' (Wiley: New York.)

Jenkinson, D. S., and Ladd, J. N. (1981). Microbial biomass in soil: measurement and turnover. In 'Soil Biochemistry'. Vol. 5. (Eds E. A. Paul and J. N. Ladd.) pp. 415-71. (Marcel Dekker: New York.)

Jenkinson, D. S., and Powlson, D. S. (1976). The effects of biocidal treatments on metabolism in soil. V. A method for measuring soil biomass. Soil Biol. Biochem. 8, 209-13.

Jones, C. A., Ratliff, L. F., and Dyke, P. T. (1982). Estimation of potentially mineralizable soil nitrogen from chemical and taxonomic criteria. Commun. Soil Sci. Plant Anal. 13, 75-86.

Ladd, J. N., Amato, M., and Parsons, J. W. (1977). Studies of nitrogen immobilization and mineralization in calcareous soils. III. Concentration and distribution of nitrogen derived from the soil biomass. In 'Soil Organic Matter Studies'. Vol. 1, pp. 301-10. (International Atomic Energy Agency: Vienna.)

Legg, J. O., Chichester, F. W., Stanford, G., and Demar, W. H. (1971). Incorporation of ${ }^{15} \mathrm{~N}$-tagged mineral nitrogen into stable forms of soil organic nitrogen. Soil Sci. Soc. Am. Proc. 35, 273-6.

McGill, W. B., Cannon, K. R., Robertson, J. A., and Cook, F. D. (1986). Dynamics of soil microbial biomass and water-soluble organic $\mathrm{C}$ in Breton $\mathrm{L}$ after 50 years of cropping to two rotations. Can. J. Soil Sci. 66, 1-19.

Oades, J. M., and Jenkinson, D. S. (1979). The adenosine triphosphate content of the soil microbial biomass. Soil Biol. Biochem. 11, 201-4.

Richter, J., Nuske, A., Habenicht, W., and Bauer, J. (1982). Optimized N-mineralization parameters of loess soils from incubation experiments. Plant Soil 68, 379-88.

Shen, S. M., Pruden, G., and Jenkinson, D. S. (1984). Mineralization and immobilization of nitrogen in fumigated soil and the measurement of microbial biomass nitrogen. Soil Biol. Biochem. 16, 437-44. 
Smith, J. L., Schnabel, R. R., McNeal, B. L., and Campbell, G. S. (1980). Potential errors in the first-order model for estimating soil nitrogen mineralization potentials. Soil Sci. Soc. Am. J. 44, 996-1000.

Smith, S. J., Young, L. B., and Miller, G. E. (1977). Evaluation of soil nitrogen mineralization potentials under modified field conditions. Soil Sci. Soc. Am. J. 41, 74-6.

Stanford, G., Carter, J. N., and Smith, S. J. (1974). Estimates of potentially mineralizable soil nitrogen based on short-term incubation. Soil Sci. Soc. Am. Proc. 38, 99-102.

Stanford, G., and Smith, S. J. (1972). Nitrogen mineralization potentials of soils. Soil Sci. Soc. Am. Proc. 36, 465-72.

Voroney, R. P., and Paul, E. A. (1984). Determination of $k_{\mathrm{C}}$ and $k_{\mathrm{N}}$ in situ for calibration of the chloroform fumigation-incubation method. Soil Biol. Biochem. 16, 9-14.

Manuscript received 4 February 1987, accepted 16 April 1987 